\title{
Infestação pelo Ácaro Varroa destructor (Anderson \& Trueman) (Mesostigmata: Varroidae) em Operárias Adultas e em Células de Cria de Abelhas Africanizadas Apis mellifera Linnaeus (Hymenoptera: Apidae) na Região de Franca-SP
}

\author{
Aline Patricia Turcatto ${ }^{\circledR}$, Marcia Cavichio Issa ${ }^{1}$, Michelle Manfrini Morais ${ }^{1}$, Rosana Almeida ${ }^{2}$
}

1. Universidade de São Paulo, e-mail: alinepatricia@usp.br (Autor para correspondência ${ }^{\bowtie}$ ), mrcissa@rge.fmrp.usp.br, mmanfrini@rge.fmrp.usp.br. 2. Universidade de Franca, e-mail: rosana.bio@unifran.br.

EntomoBrasilis 5 (3): 198-203 (2012)

Resumo. O ácaro Varroa destructor (Anderson \& Trueman) tem sido, até hoje, uma das pragas que mais causa danos à apicultura mundial, isolada ou associada a outras doenças apícolas. Foram avaliados os índices de infestação por $V$. destructor em operárias adultas e em células de cria para averiguar como esses índices variam, no outono e início de inverno, em um apiário de abelhas africanizadas localizado em uma região com clima tropical e alimento na natureza, uma vez que outono é a estação onde ocorrem maiores infestações. As amostras foram coletadas em 2005 (maio e junho) em 2007 (abril e junho) no apiário experimental da Universidade de Franca-UNIFRAN em Restinga-SP. Os índices médios de infestação em crias foram maiores em maio/2005 (12,44\%) do que em junho/2005 (7,78\%) e também foram maiores em abril/2007 (3\%) do que em junho/2007 (o\%); diferenças não estatisticamente significantes. Os índices médios de infestação em operárias adultas foram menores em maio/2005 (0,95\%) do que em junho/2005 (1,90\%) e também menores em abril/2007 (0,90\%) do que em junho/2007 (4,43\%); diferença estatisticamente significante em $2007(\mathrm{P}=0,031)$. Essa tendência de variação das médias em adultos e crias, durante os meses de outono e início de inverno, foi a mesma nos índices individuais em todas as colônias analisadas em 2005 e 2007 (exceto colônia 11/2005). Com relação às infestações em abelhas africanizadas observamos ainda: muitas colônia apresentaram índice $0 \%$ de infestação; algumas apresentaram infestações maiores do que outras, cujos índices em crias diminuíram já em junho. Em junho, quase início do inverno, seria esperado ainda encontrar índices mais elevados de infestação (e até mortalidade), em adultos como em crias, mas a infestação em crias começou baixar já em junho nesse apiário. Isso pode estar sendo uma constante nas abelhas africanizadas que mesmo passando por situações críticas no outono/inverno, quando as temperaturas baixam e ocorre diminuição de alimento na natureza, voltam a se recuperar quando as temperaturas se elevam, principalmente se há alimento disponível, como Restinga-SP, que está em uma mata de cerrado cercada por cana-de-açúcar, cuja safra inicia em março/abril. Assim, parece que suas colônias se recuperaram mais rápido das infestações de outono/inverno do que colônias em outras localidades.

Palavras-Chaves: Alimento; Apicultura; Temperatura; Varroose.

Incidence of the Mite Varroa destructor (Anderson \& Trueman) (Mesostigmata: Varroidae), in Adult Worker Bees and Brood Cells of Africanized Honey Bees, Apis mellifera Linnaeus (Hymenoptera: Apidae) in the Franca Region of São Paulo State in Brazil

Abstract. The mite Varroa destructor (Anderson \& Trueman), has been, until now, one of the pest that causes more damage to the beekeeping worldwide, alone or associated with another bee diseases. Several factors affects the variation of the indexes of infestation and reproduction, such as climate, bee breed, development time, hygienic behavior; being that temperature is a environmental variable that acts on the variation of these indexes: the infestation increases in the colder months and decrease in warmer months, so in the months of autumn and winter occurs the biggest infestation by varroa in the beehives. Were evaluated the indexes of infestation by $V$. destructor on adult worker and brood cells to ascertain how these indexes rates, in months of autumn, in an africanized bees apiary located in region of Cerrado, surrounded by plantations of sugar cane, with a tropical climate and food in nature. The sample was collected in two years, in the months of May and June 2005 and April and June 2007 in the Experimental Apiary of Franca University-UNIFRAN, located in the municipality of Restiga-SP. The medium indexes of infestation in broods were higher in May/2005 (12.44\%) than June/2005 (7.78\%), were also higher in April/2007 (3\%) than in June/2007 (0\%); all the differences weren't statistically significant. The medium indexes of infestation in adult workers were lesser in May/2005 (0.95\%) than June/2005 (1.90\%) and lesser in April/2007 (0.90\%) than in June/2007 (4.43\%); the difference observed in 2005 was not statistically significant, unlike that observed in $2007(\mathrm{P}=0.031)$.

Keywords: Beekeeping; Food; Temperature; Varroosis.

$\mathrm{O}$ ácaro Varroa destructor (Anderson \& TRUEMAN 2000) é um ectoparasita de crias e indivíduos adultos de abelhas do gênero Apis. Somente na década de 6o, em Moscou, o ácaro $V$. destructor foi observado parasitando abelhas Apis mellifera Linnaeus (Shabanov et al. 1978; Smirnov 1978), desde então, o ácaro se espalhou por todo o mundo, causando sérios danos à apicultura mundial, sendo até hoje, uma das pragas que mais causam problemas à apicultura comercial em grande parte do mundo (DE Jong 1997).
Em abelhas A. meliffera, a infestação ocorre tanto nas crias de zangões como nas de operárias, zangões são mais infestados (Grobov 1977), também nas africanizadas (Issa et al. 1985). As fases de desenvolvimento do ácaro Varroa destructor são: ovo, larva, protoninfa, deutoninfa e adulto. O período de desenvolvimento dura de sete a oito dias para fêmeas e de cinco a seis dias para machos (Groвоv 1977). Apresenta acentuado dimorfismo sexual, os machos têm o corpo mole e amarelado, de forma arredondada, medindo 0,75 × 0,80 mm; as fêmeas têm 
cor marron, corpo duro e elíptico, achatado dorso-ventralmente, medindo de 1,00 a $1,08 \mathrm{~mm}$ de comprimento por 1,58 a 1,71 $\mathrm{mm}$ de largura. Seu aparelho bucal apresenta quelíceras na parte externa adaptadas para perfurar a quitina das abelhas. Os machos não se alimentam, pois suas quelíceras são modificadas para o transporte de espermatóforos (DE JoNG 1997). As fêmeas fertilizadas do ácaro entram nas células desoperculadas de cria das abelhas entre o quinto e o sexto dia do desenvolvimento larval para se reproduzirem, levadas pelas abelhas nutrizes, durante o seu trabalho de alimentação das larvas (Groвоv 1977; Issa et al. 1993a), iniciando o ciclo reprodutivo. As fêmeas do ácaro só deixam o corpo da abelha adulta (onde se alimentam de hemolinfa) quando procuram uma célula de cria para se reproduzirem. Uma ou várias fêmeas podem penetrara na célula de cria, indo rapidamente para baixo da larva e permanecendo inerte no alimento larval (DE Jong 1997). Depois que o alimento é consumido pela larva, o ácaro passa a se alimentar da hemolinfa da pré-pupa, em pequenas quantidades e durante intervalos regulares (DE JoNG 1984). Os ovos são colocados nas paredes das células (SMirnov 1978), em número máximo de seis ovos em células de operárias (IFANTIDIs 1983). O primeiro ovo é um macho e os demais fêmeas. O acasalamento ocorre dentro da célula operculada (Groвov 1977) e as fêmeas adultas do ácaro já fertilizadas abandonam as células de cria fixadas ao corpo da abelha que irá emergir, iniciando o ciclo forético. Os machos e os ácaros imaturos morrem na célula de cria da abelha (DE Jong 1977).

Estudos estão sendo realizados no sentido de se conhecer melhor os fatores que afetam a reprodução, e a infestação pelo ácaro $V$. destructor como: condições climáticas (MARIN 1978; ENGELS et al. 1986; MoretTo et al. 1991), tipo de apicultura (MARIN 1978), densidade da colônia (MARIN 1978; Buriolla \& GONÇALVES 1983), raças de abelhas (MARIN 1978; ENGELs et al. 1986; MoRETTO et al. 1991), tamanho das células onde as larvas de abelhas se desenvolvem (Issa et al. 1993b; Message \& GonÇAlves, 1995), tempo de desenvolvimento das larvas (Moritz \& HäNEL 1984; ROSENKRANZ et al. 1988), comportamento de limpeza das abelhas operárias e adultas (Moritz \& (MAUTZ 1990) e presença de realeira na colônia (De Jong 1981; Issa et al. 1984). Segundo Rinderer et al. (1993), tanto a genética quanto o ambiente são aspectos importantes na resistência e tolerância à $V$. destructor.

O objetivo do presente trabalho consistiu na avaliação da variação dos índices de infestação pelo ácaro $V$. destructor em operárias adultas e em células de cria de abelhas africanizadas A. mellifera L. nos meses do outono e início de inverno, para averiguar como esses índices variam em um apiário localizado em um a região com clima tropical, no estado de São Paulo e com oferta de alimento na natureza (vegetação de cerrado cercado por plantações de cana-de-açúcar); sendo que, de maneira geral, o outono é a estação onde ocorre a maior infestação pelo ácaro (SMirnov 1978) e em países com clima tropical, como o Brasil, a maior mortalidade das abelhas, causada por varroa e outras acarioses, ocorre entre o outono e a primavera (DE Jong et al. 1984; De Jong 1989).

\section{MATERIAL E MÉTODOS}

As amostras foram coletadas em dois anos nos meses de maio e junho de 2005, em cinco colônias de abelhas africanizadas, e nos meses de abril e junho de 2007 em quatro colônias no apiário experimental da Universidade de Franca - UNIFRAN, instalado na Fazenda Princesa dos Campos, município de Restinga-SP (Latitude $20^{\circ} 36^{\prime} 11^{\prime \prime} \mathrm{S}$, Longitude $47^{\circ} 28^{\prime} 58^{\prime \prime} \mathrm{W}$ ) com altitude de $910 \mathrm{~m}$ e distante $20 \mathrm{~km}$ de Franca-SP. As colmeias permaneceram no local por um período de quatro anos; a área possui uma vegetação típica de cerrado, de aproximadamente cinco alqueires, circundada por uma vasta plantação de cana-de-açúcar.

O clima tropical de altitude é característico da região, com chuvas no verão e seca no inverno; os meses mais chuvosos vão de outubro a março (primavera e verão) e os mais secos de junho a agosto (inverno). Os meses mais quentes vão de novembro a março (primavera e verão), com temperaturas médias variando de $19^{\circ} \mathrm{C}$ a $29^{\circ} \mathrm{C}$. Em abril, início do outono, com o término dos meses quentes e chuvosos, as temperaturas começam a cair, chegando a ocorrer períodos com alternância de dias quentes (até $32^{\circ} \mathrm{C}$ ) com noites frias $\left(15^{\circ} \mathrm{C}-17^{\circ} \mathrm{C}\right)$ o que leva a uma grande variação de temperatura.

Para a análise dos índices de infestação em operárias adultas (número de ácaros/número de abelhas), as abelhas foram coletadas em álcool 70\% e submetidas à agitação mecânica por cerca de 10 minutos. O álcool com as abelhas adultas foi filtrado em uma malha branca, que permite a visualização e contagem dos ácaros (STORT et al. 1981). Para a verificação dos índices de infestação em células de cria de operárias (número de ácaros/ número de células), foi utilizada cria operculada na fase de pupa, sendo investigadas 100 células aleatoriamente, 50 em cada face do favo (GONÇALVES et al. 1980).

Para o processamento das análises estatísticas, foi utilizado o programa Jandel Scientific Sigma Stat 3.1. Os dados, em porcentagem, foram transformados em arco-seno, antes da aplicação dos testes. Para as análises de comparação entre dois grupos, foram aplicados os testes Mann-Whitney e t-Student.

O valor escolhido para o índice de significância das amostras foi de $\alpha=5 \%$.

\section{RESULTADOS}

A primeira coleta, realizada em cinco colônias de abelhas africanizadas nos meses de maio e junho de 2005 (colônias 07, $08,11,12,13)$, outono e início do inverno, permitiu calcular os índices de infestação pelo ácaro $V$. destructor em operárias adultas e em células de cria (Tabela 1).

O índice médio de infestação em operárias adultas, nas colônias analisadas em 2005, foi menor em maio/2005 (0,95\%) do que em junho/2005 (1,90\%), esta diferença não foi estatisticamente significante, com $\mathrm{P}=0,222$ (Tabela 1 ).

Os índices individuais de infestação em operárias adultas observados em cada colônia , com exceção da colônia 11, exibiram o mesmo comportamento. Esses valores foram $0 \% \mathrm{em}$ maio/2005 nas colônias 07, 08, 13 e 14 e aumentaram para 0,98\%, 2,04\%, $1,31 \%$ e 5,17\%, respectivamente, em junho/2005. Na colônia 11 , os valores foram $4,76 \%$ em maio e o\% em junho (Tabela 1).

O índice médio de infestação em crias, nas colônias analisadas em 2005, foi maior em maio/2005 (12,44\%) do que em junho/2005 $(7,78 \%)$, diferença estatisticamente não significante, com $\mathrm{P}=0,267$ (Tabela 1).

Assim, como para as operárias adultas, os índices individuais de infestação em crias observado em cada colônia, com exceção da colônia 11, exibiram o mesmo comportamento. Esses valores foram 18\%, 19,23\%, 13\% e 11\% em maio/2005 nas colônias 07, 08, 13 e 14 e diminuíram para $15,90 \%, 3 \%, 8 \%$ e $6 \%$, em junho/2005. Na colônia 11, os valores foram $1 \%$ em maio e $6 \%$ em junho (Tabela 1).

A segunda coleta, realizada em quatro colônias de abelhas africanizadas nos meses de abril e junho de 2007 (colônias 08, 12, 13 e 14), outono e início do inverno, permitiu calcular os índices de infestação pelo ácaro $V$. destructor em operárias adultas e em células de cria (Tabela 2).

O índice médio de infestação em operárias adultas, nas colônias analisadas em 2007, foi menor em abril/2007 (0,90\%) do que em junho/2007 (4,43\%), diferença estatisticamente significante, com $\mathrm{P}=0,031$ (Tabela 2).

Os índices individuais de infestação em operárias adultas 
observados em cada colméia exibiram o mesmo comportamento. Esses valores foram 0,84\%, 0\%, 2,77\% e 0\%, em abril/2007 nas colônias 08, 12, 13 e 14 e aumentaram para 5,95\%, 2,08\%, 6,50\% e 3,18\%, respectivamente, em junho/2007 (Tabela 2).

Analisando ainda os índices individuais de infestação em operárias adultas, podemos dizer que ocorreram dois modos de resposta das colônias em relação à infestação. As colônias 08 e 13, no início do experimento (abril) apresentaram o,84\% e 2,77\%, respectivamente, e em junho aumentaram para 5,95\% e 6,50\%; as colônias 12 e 14 começaram o experimento (abril) com o\% de infestação e estavam com 2,08\% e 3,18\%, respectivamente, em junho (Tabela 2).

O índice médio de infestação em células de cria, nas colônias analisadas em 2007, foi maior em abril/2007 (3\%) do que em junho/2007 (o\%), diferença estatisticamente não significante, com $\mathrm{P}=0,343$ (Tabela 2).

Os índices individuais de infestação em células de cria observados em cada colméia exibiram o mesmo comportamento. Esses valores foram $4 \%, 0 \%, 8 \%$ e $0 \%$, em abril/2007 nas colônias o8, 12, 13 e 14 e diminuíram para o\% em todas as colônias, em junho/2007 (Tabela 2).

Do mesmo modo que para as operárias adultas, analisando ainda os índices individuais de infestação em células de cria, podemos dizer que ocorreram dois modos de resposta das colônias em relação à infestação. As colônias 08 e 13, no início do experimento (abril), apresentaram infestação de 4\% e 8\%, respectivamente, e em junho ambas estavam com $0 \%$. As colônias 12 e 14 começaram o experimento com $0 \%$ de infestação em crias e permaneceram com zero (Tabela 2).

A comparação dos valores médios das infestações em operárias adultas e em células de cria em 2005 e 2007 mostrou semelhança na infestação em operárias adultas com 0,95\% em maio/2005 (Tabela 1) e 0,90\% em abril/2007 (Tabela 2), diferença na infestação em operárias adultas com 1,90\% em junho/2005 (Tabela 1) e 4,43\% em junho/2007 (Tabela 2), diferença na infestação em células de cria com 12,44\% em maio/2005 (Tabela 1) e $3 \%$ em abril/2007 (Tabela 2) e diferença na infestação em células de cria com 7,78\% em junho/2005 (Tabela 1) e o\% em junho/2007 (Tabela 2).

\section{DISCUSSÃO}

O apiário experimental da Universidade de Franca é um apiário onde se espera que as abelhas sofram pouca influência das quedas de temperatura e das doenças oportunistas, que ocorrem no outono/inverno, e também que se estabilizem os índices de infestação com maior rapidez para a primavera, já que há alimento disponível na natureza (mata de cerrado e cana-deaçúcar) e pouco manuseio para as pesquisas, permanecendo no local por quaro anos .

De maneira geral, no Brasil, os índices de infestação, tanto em adultos como em crias variam de acordo com as estações do ano, sendo maiores no final do verão e início do outono (abril/maio), período em que as temperaturas começam a declinar (DE Jong et al. 1984; Engels et al. 1986; MoretTo et al. 1991). Rocha \& LARA (1994), analisando infestações pelo ácaro em abelhas adultas no Rio Grande do Sul, mostraram que a temperatura foi a única variável ambiental que apresentou correlação com o parasitismo por varroa e que a infestação aumenta nos meses mais frios e diminui nos meses mais quentes. Em crias, ocorre um acentuado aumento da infestação no final do verão (DE Jong et al. 1984; DE JoNG 1997). Na região de Franca-SP, os meses mais quentes vão de novembro a março (primavera/verão), quando então, em abril (início do outono), um dos meses selecionados para avaliar as infestações nesta pesquisa, as temperaturas começam a baixar, chegando a ter períodos com grande variação de temperatura com dias quentes (até cerca de $33^{\circ} \mathrm{C}$ ) alternando com noites frias

\section{$\left(15^{-1} 7^{\circ} \mathrm{C}\right)$.}

No final do outono e início do inverno a infestação nas abelhas adultas tendem a continuar aumentando (ENGELs et al. 1986; Moretto et al. 1991; Pegoraro et al. 2000); mesmo no Brasil, quase que totalmente ocupado pelas abelhas africanizadas, são encontradas infestações mais altas em regiões com temperaturas mais baixas (DE Jong et al. 1984). E os índices de infestação em crias tendem a baixar com a chegada da primavera e verão (DE Jong 1984; De Jong et al., 1984; DE JoNG 1997 ).

Assim, os índices médios de infestação em operárias adultas, observados neste trabalho, variaram no outono de acordo com o esperado. Foram menores em maio/2005 (o,95\%) do que em junho/2005 (1,90\%) e também foram menores em abril/2007 (0,90\%) do que em junho/2007 (4,43\%), com diferenças não significantes em 2005, mas significante em 2007. Isso se repetiu em todas as colônias, com exceção da colônia 11 em 2005. Considerando as várias formas de dispersão e os fatores que favorecem a infestação e a reprodução do ácaro $V$. destructor, seria esperado esse aumento nos índices de infestação nas operárias adultas de abril para junho pelo fato de serem os meses onde ocorrem temperaturas mais baixas, durante o outono/ inverno. Pegoraro et al. (2000) analisando abelhas adultas no Paraná mostraram que o inverno é a estação onde o grau de infestação por $V$. destructor é mais elevado.

Os índices médios de infestação em células de crias, observados neste trabalho, também variaram no outono conforme o esperado, foram maiores em maio/2005 (12,44\%) do que em junho/2005 (7,78\%) e também foram maiores em abril/2007 (3\%) do que em junho/2007 (o\%); essas diferenças não foram estatisticamente significantes. Isso se repetiu em todas as colônias, com exceção da colônia11 em 2005. Os índices de infestação em crias aumentam muito no final do verão e depois tendem a cair com a chegada da primavera e verão (DE Jong et al. 1984; DE Jong 1997).

Neste trabalho, com a análise da variação das médias e dos índices individuais de infestação por colônia, observamos, ainda, algumas características no apiário em Restinga-SP relacionadas às infestações pelo ácaro em abelhas africanizada, descritas a seguir.

Algumas colônias apresentaram maiores índices de infestação durante o outono e início do inverno do que outras. Isso ocorre com algumas colônias que são mais sensíveis às infestações e demais pragas apícolas, mesmo em abelhas africanizadas, que são resistentes a várias doenças (DE JoNG \& GonçALves 1998; ISSA et al. 2012), mas mesmo elas voltaram a ter a infestação variando entre $0 \%$ e 3\%, como a infestação em crias na colônia 08 em 2005 , que foi $19,23 \%$ em maio e baixou para $3 \%$ logo em junho (Tabela 1). As infestações nas abelhas africanizadas tendem a variar em torno de o\%-3\% (DE Jong \& GONÇALVES 1998).

Ocorreram dois tipos de resposta à infestação pelo ácaro nas colônias em 2007, podendo separá-las em dois lotes de acordo com os índices individuais de infestação. As colônias o8 e 13 foram mais infestadas do que as colônias 12 e 14 tanto em operárias adultas como em crias. Em células de cria, as colônias o8 e 13 estavam com $4 \%$ e $8 \%$ de infestação em abril, enquanto as colônias 12 e 14 estavam ambas com o\% (Tabela 2). As colônias 8 e 13, que apresentaram maiores índices de infestação, em operárias adultas estavam com o,84\% e 2,77\% em abril e aumentaram para $5,95 \%$ e 6,50\% em junho; as colônias 12 e 14 em abril estavam ambas com o\% de infestação e aumentaram apenas para 2,08\% e 3,18\% em junho (Tabela 2). Essa variação é uma constante em abelhas africanizadas (GONÇALVES 1986).

Muitas colônias apresentaram índice o\% de infestação. Isso é uma constante nas abelhas africanizadas, cujos índices de infestação têm gradativamente diminuído (GonçALves 1986; MoretTo et al. 1995; DE Jong \& GonçALVES 1998), principalmente no estado de São Paulo, onde se localiza o apiário analisado. Os 
índices individuais de infestação em adultos em maio/2005 e abril/2007 foram 0\% em quase todas as colônias, com exceção da colônia 11 em 2005 (Tabela 1) e das colônias o8 e 13 em 2007 (Tabela 2). Os índices individuais de infestação em crias mostraram que nenhuma colônia esteve com o\%, tanto em maio como em junho de 2005 (Tabela 1); já em 2007 as colônias 12 e 14 estavam ambas com o\% e as colônias o8 e13 estavam com 4\% e 8\% de infestação em abril; todas estavam com o\% em junho (Tabela 2). Isto sugere que pode ter havido uma infestação mais acentuada em 2005 do que em 2007, pois mesmo em abelhas africanizadas e em clima tropical os índices de infestação podem variar dependendo da oscilação da temperatura local ano a ano.

A comparação dos valores médios dos índices de infestação tanto em operárias adultas como em células de cria, neste trabalho, mostraram que esses índices foram numericamente diferentes entre si nos dois outonos avaliados, 2005 (Tabela 1) e 2007 (Tabela 2), com exceção da infestação em operárias adultas que tiveram valores semelhantes em maio/2005 (0,95\%) e abril/2007 (o,90\%). Isso demonstra que as infestações médias no estado de São Paulo estão se mantendo baixas (DE JoNG \& GonçALVES 1998; IssA et al. 2012).

As comparações das variações nos índices médios de infestação pelo ácaro nas colônias em Restinga-SP, no outono e início do inverno, foram estatisticamente significantes apenas em operárias adultas em 2007, mas as médias e os índices individuais de infestação mostraram a mesma tendência de variação em todas as colônias analisadas (com exceção da colônia 11 em 2005), em operárias adultas e crias, nos 2 anos de experimento (Tabela1 e Tabela 2); aumentando em operárias adultas de abril/maio para junho e diminuindo em cria no mesmo período.

Isso pode estar sendo uma constante nas abelhas africanizadas que mesmo passando por situações críticas no outono e inverno, quando as temperaturas baixam e ocorre diminuição de alimento na natureza, voltam a se recuperar quando as temperaturas se elevam, principalmente se há alimento disponível.

Em junho, quase início do inverno, ainda seria esperado encontrar índices mais elevados de infestação, tanto em adultos como em crias, mas a infestação em crias baixou de 12,44\% em maio/2005 para 7,78\% em junho/2005; mesmo a colônia 08 em 2005 baixou de 19,23\% em maio para 3\% em junho (Tabela 1). Em 2007, todas as colônias desse apiário já estavam sem ácaro em junho/2007, com infestação 0\%; a infestação em crias baixou de $3 \%$ em abril/2007 para o\% em junho/2007 (Tabela 2). Parece que em 2007 houve uma reação mais positiva das abelhas em relação à infestação pelo ácaro do que em 2005. Aqui também pode-se inferir que essa diferença na variação da infestação, entre 2005 e 2007, pode ter sido causada pela oscilação das temperaturas locais dentro da mesma estação, que mudam ano a ano. Outro fato importante, é que a maioria das colônias, em Restinga-SP, apresentaram o\% a 1\% de infestação em operárias adultas no começo do experimento, início do outono, tanto em maio de 2005 (Tabela 1) como abril de 2007 (Tabela 2); com esses resultados podemos inferir que apesar dos índices de infestação em adultos crescerem, nesse apiário, durante os meses mais frios, eles voltam a baixar quando as temperaturas se elevam.

Essas colônias estão localizadas em uma região de clima tropical, no estado de São Paulo, com oferta de alimento na natureza numa mata de cerrado ( 5 alqueires) cercada por cana-de-açúcar (11 alqueires), cuja safra inicia em março/abril. Presença de alimento é um dos fatores que pode favorecer o crescimento das populações do ácaro (DE Jong et al. 1984) e em pesquisa no sul do Brasil, nos meses mais frios, com a redução da oferta de alimento foram registradas infestações maiores em operárias adultas (Pegoraro et al. 2000). Sendo essa uma região com características na oferta de alimento bem diversa do que enfrentam as abelhas no outono/inverno em outras regiões do Brasil, que são mais frias ou, ainda, com pequena oferta de alimento na natureza,

Tabela 1. Índices de infestação (\%) do ácaro Varroa destructor em operárias adultas e em células de cria, em cinco colônias de abelhas africanizadas (Apis mellifera), avaliados nos meses de maio e junho de 2005 (meio e final do outono).

\begin{tabular}{|c|c|c|c|c|}
\hline \multirow{3}{*}{$\mathbf{N}^{\circ}$ Colônia } & \multicolumn{4}{|c|}{ Índices de Infestação } \\
\hline & \multicolumn{2}{|c|}{ Operárias Adulta } & \multicolumn{2}{|c|}{ Células de Cria } \\
\hline & $\begin{array}{c}\text { Maio } \\
\text { ( } \mathrm{n}^{\circ} \text { ácaros } / \mathbf{n}^{\circ} \text { abelhas) }\end{array}$ & $\begin{array}{c}\text { Junho } \\
\text { ( } \mathrm{n}^{\circ} \text { ácaros } / \mathbf{n}^{\circ} \text { abelhas) }\end{array}$ & $\begin{array}{c}\text { Maio } \\
\text { ( } \mathrm{n}^{\circ} \text { ácaros } / \mathbf{n}^{\circ} \text { abelhas) }\end{array}$ & $\begin{array}{c}\text { Junho } \\
\text { ( } \mathrm{n}^{\circ} \text { ácaros } / \mathrm{n}^{\circ} \text { abelhas) }\end{array}$ \\
\hline 07 & $\mathbf{o}(0 / 60)$ & $\mathbf{0 , 9 8}(1 / 102)$ & $18(18 / 100)$ & $\mathbf{1 5 , 9}(7 / 44)$ \\
\hline 08 & o $(0 / 47)$ & $\mathbf{2 , 0 4}(2 / 98)$ & $19,23(15 / 78)$ & $3(3 / 100)$ \\
\hline 11 & $\mathbf{4 , 7 6}(3 / 63)$ & $\mathbf{o}(\mathrm{o} / 36)$ & $1(1 / 100)$ & $6(6 / 100)$ \\
\hline 13 & $\mathbf{o}(0 / 85)$ & $\mathbf{1 , 3 1}(1 / 76)$ & $13(13 / 100)$ & $8(8 / 100)$ \\
\hline 14 & $\mathbf{o}(\mathrm{o} / 129)$ & $\mathbf{5 , 1 7}(3 / 58)$ & $11(11 / 100)$ & $6(6 / 100)$ \\
\hline Médias & $0,95^{*}$ & $1,90^{*}$ & $12,44^{* *}$ & $7,78^{* *}$ \\
\hline
\end{tabular}

*Mann-Whitney Rank Sum Test: os índices médios de infestação em células de crias observados nos meses de maio e junho não diferem estatisticamente entre si $(\mathrm{P}=0,222)$.

** Teste $t$-Student: os índices médios de infestação em células de crias observados nos meses de maio e junho não diferem estatisticamente entre si $(\mathrm{P}=0,267)$.

Tabela 2. Índices de infestação (\%) do ácaro Varroa destructor em operárias adultas e em células de cria, em quatro colônias colmeias de abelhas africanizadas (Apis mellifera), avaliados nos meses de abril e junho de 2007 (início e final do outono).

\begin{tabular}{|c|c|c|c|c|}
\hline \multirow{3}{*}{$\mathbf{N}^{\circ}$ Colônia } & \multicolumn{4}{|c|}{ Índices de Infestação } \\
\hline & \multicolumn{2}{|c|}{ Operárias Adulta } & \multicolumn{2}{|c|}{ Células de Cria } \\
\hline & $\begin{array}{c}\text { Maio } \\
\text { (n ácaros/ } \mathbf{n}^{\circ} \\
\text { abelhas) }\end{array}$ & $\begin{array}{c}\text { Junho } \\
\text { ( } \mathrm{n}^{\circ} \text { ácaros/ } \mathrm{n}^{\circ} \\
\text { abelhas) }\end{array}$ & $\begin{array}{c}\text { Maio } \\
\text { ( } \mathrm{n}^{\circ} \text { ácaros } / \mathrm{n}^{\circ} \\
\text { abelhas) }\end{array}$ & $\begin{array}{c}\text { Junho } \\
\text { (n }{ }^{\circ} \text { ácaros/ } \mathbf{n}^{\circ} \\
\text { abelhas) }\end{array}$ \\
\hline 08 & $\mathbf{0 , 8 4}(\mathrm{o} / 118)$ & $\mathbf{5 , 9 5}(5 / 84)$ & $4(4 / 100)$ & $\mathbf{o}(0 / 100)$ \\
\hline 12 & $\mathbf{o}(\mathrm{o} / 271)$ & $\mathbf{2 , 0 8}(2 / 96)$ & $\mathbf{o}(\mathrm{o} / 100)$ & $\mathbf{o}(0 / 100)$ \\
\hline 13 & $\mathbf{2 , 7 7}(4 / 144)$ & $\mathbf{6 , 5 0}(8 / 123)$ & $8(8 / 100)$ & $\mathbf{o}(0 / 100)$ \\
\hline 14 & o $(0 / 287)$ & $\mathbf{3 , 1 8}(5 / 157)$ & $\mathbf{o}(0 / 100)$ & $\mathbf{o}(0 / 100)$ \\
\hline Médias & $0,90^{*}$ & $4,43^{*}$ & $3^{* * *}$ & $\mathbf{O}^{* * *}$ \\
\hline
\end{tabular}

*Teste $t$-Student: há diferença estatisticamente significante $(\mathrm{P}=0,031)$, nos índices médios de infestação em abelhas adultas, entre os meses de abril e junho.

**Mann-Whitney RankSum Test: os índices médios de infestação em células de crias observados nos meses de abril ejunho não diferem estatisticamente $(\mathrm{P}=0,343)$. 
onde as abelhas precisam ser alimentadas durante o outono/ inverno para sobreviverem (ou não enxamearem), como no apiário experimental da USP de Ribeirão Preto-SP (distante apenas $100 \mathrm{Km}$ de Franca-SP), com o mesmo clima tropical, mesma variação intensa de temperatura no outono/inverno, mas redução da oferta de alimento na natureza no outono/inverno quando as temperaturas baixam.

Em operárias adultas, os índices de infestações aumentaram de abril/maio para junho, seguindo a tendência natural de aumento dessa infestação, mas a maioria das colônias estavam com o\% em abril/maio, no início do outono, quando iniciamos o experimento, nos 2 anos de coleta (2005 e 2007), podendo-se inferir que as infestações aumentam até o inverno, depois caem quando as temperaturas se elevam, com muitas colônias apresentando o\% em Restinga-SP. Em crias, a maioria das colônias desse apiário apresentaram infestação o\% já em junho, quando ainda seriam esperadas infestações mais altas e até mortalidade, uma vez que em países com clima tropical, como o Brasil, a maior mortalidade das abelhas, causada por varroa e outras acarioses, ocorre entre o outono e a primavera (DE JoNG 1989) e os índices de infestação em células de cria tendem a diminuir com a chegada da primavera e verão (DE Jong et al. 1984; DE Jong 1997), mas em Restinga-SP baixaram já em junho (quase início do inverno).

Isso pode estar sendo uma constante nas abelhas africanizadas que mesmo passando por situações críticas no outono/inverno, com a ocorrência de doenças oportunistas, sob temperaturas baixas e redução na oferta de alimento na natureza, voltam a se recuperar quando as temperaturas se elevam, principalmente se há alimento disponível, como em Restinga-SP.

Assim, as colônias desse apiário reagiram melhor ao aumento da infestação pelo ácaro $V$. destructor no outono e início do inverno, do que outras com redução da oferta de alimento na natureza ou em climas mais frios, parecendo ter-se estabilizado para a primavera mais cedo que as demais.

\section{AGRADECIMENTOS}

Ao Prof. Dr. Tiago M. Francoy pela ajuda com as análises estatísticas. Ao Dr. David de Jong pelos comentários e sugestões. Os autores agradecem à Fapesp (Proc. 96/05422-3 e 2007/07701-3) e à Capes pelo apoio financeiro.

\section{REFERÊNCIAS}

Anderson, D.L. \& J.W.H. Trueman, 200o. Varroa jacobsoni (Acari:Varroidae) is more than one species. Experimental and Applied Acarology, 24: 165-189.

Buriolla, A.H. \& L.S. Gonçalves, 1983. Comparação entre o tamanho da colmeia e a porcentagem de infestação pelo ácaro Varroa jacobsoni. Ciência e Cultura, 35: 712.

De Jong, D., 1981. Effect of queen cell construction on the rate of invasion of honeybee brood cells by Varroa jacobsoni. Journal of Apicultural Research, 20: 254-257.

De Jong, D., 1984. Current knowledge and open questions concerning reproduction in the honey bee mite, Varroa jacobsoni. p. 547-552. In: Engels, W. (Ed.). Advances in Invertebrate Reproduction 3. Elsevier Press, Amsterdam. $665 \mathrm{p}$.

De Jong, D., 1989. Varroa and acarine diseaes in tropical countries. In: XXXII ${ }^{\text {nd }}$ International Apicultural CongressApimondia, Rio de Janeiro, Brazil, p. 227-228.

De Jong, D., 1997. Mites: Varroa and other parasites of brood, p. 279-327. In: Morse, R.A. \& K. Flottum (Eds.). Honey Bee Pests, Predators, \& Diseases. Ohio, The A.I. Root Co, 718p.

De Jong, D. \& L.S. Gonçalves, 1998. The Africanized bees of Brazil have become tolerant to Varroa. Apiacta, XXXIII: 6570.

De Jong, D., L.S. Gonçalves \& R.A. Morse, 1984. Dependence on climate of the virulence of Varroa jacobsoni. Bee World, 65: 117-121.

Engels, W., L.S. Gonçalves, J. Steiner, A.H. Buriolla \& M.R.C. Issa, 1986. Varroa-Befall von Carnica-Völkern in Tropenklima. Apidologie, 17: 203-216.

Gonçalves, L.S., 1986. The Varroa research program in the honey bee laboratory of the University of São Paulo in Ribeirão Preto. Apidologie, 17: 371-374.

Gonçalves, L.S., A.E.E. Soares, A.C. Stort, A.H. Buriolla, M.R.C. Issa \& J. Steiner, 1980. Estudo sobre o ácaro parasita de abelhas, Varroa jacobsoni. I-Grau de infestação em apiários do Estado de São Paulo. Ciência e Cultura, 32: 678-679.

Grobov, O.F., 1977. Varroasis in bees. p. 48-90. In: V Harnaj (Ed.) Varroasis, a honey bee disease, Bucharest, Apimondia, 91p.

Infantidis, M.D., 1983. Ontogenesis of the mite Varroa jacobsoni in worker and drone honeybee brood cells. Journal of Apicultural Research, 22: 200-206.

Issa, M.R.C., D. De Jong \& L.S. Gonçalves, 1984. Influence of the presence of queen cells on the preference of Varroa jacobsoni for Apis mellifera drone brood. p. 117-121. In: Engels, W. (Ed.). Advances in Invertebrate Reproduction 3. Elsevier Press, Amsterdam, 597 p.

Issa, M.R.C., D. De Jong \& L.S. Gonçalves, 1985. Study of the preference of the mite Varroa Jacobsoni for Apis mellifera drones. In: $\mathrm{XXX}^{\text {th }}$ International Apicultural CongressApimondia. Nagoya, Japan, p. 159-16o.

Issa, M.R.C., D. De Jong \& L.S. Gonçalves, 1993a. Reproductive strategies of the mite Varroa Jacobsoni (Mesostigmata,Varroidae): Influence of larva type and comb cell size on honey bee brood infestation rates. Brazilian Journal of Genetics, 16: 219-224.

Issa, M.R.C., D. De Jong \& L.S. Gonçalves, 1993b. Estudo da infestacão de Varroa jacobsoni em indivíduos adultos em colméias de Apis mellifera africanizadas. Brazilian Journal of Genetics, 16: 326.

Issa, M.R.C., R.A. Pereira, M.M. Morais, D. De Jong \& L.S. Gonçalves, 2012. Variation in the incidence of the mite Varroa destructor in brood cells and adult workers in Africanized honey bees (Apis mellifera L.) with a high of hygienic behavior, in winter and in summer. In: X Encontro sobre Abelhas. Ribeirão Preto-SP, Brasil, p. 257-258.

Marin, M., 1978. World spread of Varroa disease. Apiacta, 13:163-166.

Message, D. \& L.S. Gonçalves, 1995. Effect of the size of worker brood cells of Africanized honey bees on infestation and reproduction of the ectoparasitic mite Varroa Jacobsoni Oud. Apidologie, 26: 381-386.

Moretto, G., L.S. Gonçalves, D. De Jong \& M.Z. Bichuette, 1991. The effects of climate and bee race on Varroa jacobsoni Oud. infestations in Brazil. Apidologie, 22: 197-203.

Moretto, G., A. Pillati, D. De Jong, L.S. Gonçalves \& F.L. Cassini, 1995. Reduction of Varroa infestations in the state of Santa Catarina, in southern Brazil. American Bee Journal, 135: 498500 .

Moritz, R.F.A. \& I.H. Hänel, 1984. Restricted development of the parasitic mite Varroa jacobsoni Oud. In the Cape honeybee, Apis mellifera capensis Esch. Zeitschrift für Angewandte Entomologie, 97: 91-95.

Moritz, R.F.A. \& D. Mautz, 1990. Development of Varroa jacobsoni in colonies of Apis mellifera capensis and Apis mellifera carnica. Apidologie, 21: 53-58

Pegoraro, A., E.M. Marques, A.C. Neto \& E.C. Costa, 2000. Infestação natural de Varroa jacobsoni em Apis mellifera scuttelata (Hymenoptera; Apidae). Archives of Veterinary Science, 5: 89-93.

Rinderer, T.E., L.I. Guzmán, J.M. Kulincevic, G.T. Delatte, L.D. Beaman \& S.M. Buco, 1993. The breeding, importing, testing and general characteristics of Yugoslavian honey bees bred for resistance to Varroa jacobsoni. Americam Bee Journal, 133: 197-200. 
Rocha, H.C. \& A.A. Lara, 1994. Flutuação populacional do ácaro Varroa jacobsoni O. em colméias de abelhas africanizadas. In: IV Congreso Iberolatinoamericano de Apicultura. Río Cuarto, Córdoba, Argentina, p. 97-100.

Rosenkranz, P., M.R.C. Issa, A. Rachinsky, A. Strambi \& C. Stambi, 1988. Honeybee-Varroa relationships: A comparison of Africanized and Carniolan colonies. p. 193-198. In: Cavalloro, R. (Ed.). Proceedings of a meeting of the ECExperts' Group. Udine, Italy, Office for Official Publications of the European Communities, Luxembourg.

Shabanov, M., S.T. Nedyalkov \& A.L. Toshkov, 1978. Varroatosis A dangerous parasitic disease on bees. American Bee Journal, 118: 402-403, 407 .
Smirnov, A.M., 1978. Research results obtained in USSR concerning aetiology, pathogenesis, epizootiology, diagnosis, and control of Varroa disease in bees. Apiacta, 13: 149-162.

Stort, A.C., L.S. Gonçalves, O. Malaspina \& F.A. Moura-Duarte, 1981. Study on Sineacar effectiveness in controlling Varroa Jacobsoni. Apidologie, 12: 289-297.

\section{Recebido em: 06/o9/2011}

Aceito em: 01/10/2012

\section{Como citar este artigo:}

Turcatto, A.P., M.C. Issa, M.M. Morais \& R. Almeida, 2012. Infestação pelo Ácaro Varroa destructor (Anderson \& Trueman) (Mesostigmata: Varroidae) em Operárias Adultas e em Células de Cria de Abelhas Africanizadas Apis mellifera Linnaeus (Hymenoptera: Apidae) na Região de Franca-SP. EntomoBrasilis, 5(3): 198-203.

Acessível em: http://www.periodico.ebras.bio.br/ojs/index.php/ebras/article/view/195

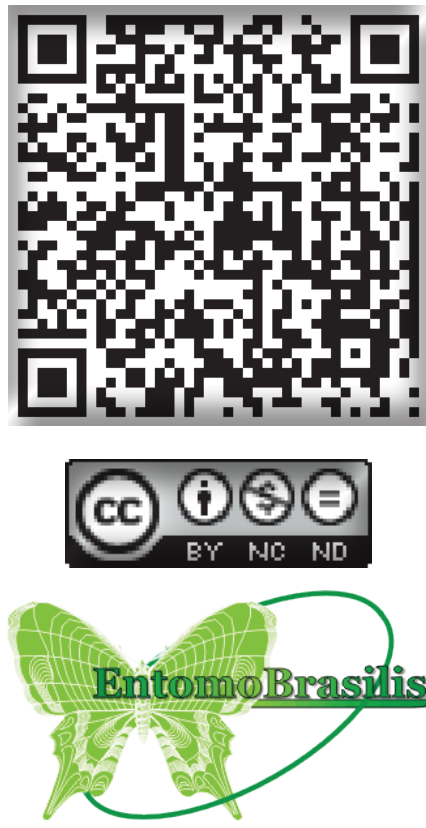

